\title{
EL CABALLERO DE LAS ESPUELAS DORADAS. ANÁLISIS ARQUEOLÓGICO DE UN ENTERRAMIENTO NOBILIARIO MEDIEVAL DEL MONASTERIO DE CORIAS
}

\author{
THE KNIGHT OF THE GOLDEN SPURS. \\ ARCHAEOLOGICAL ANALYSIS OF A MEDIEVAL \\ NOBLE BURIAL IN THE MONASTERY OF CORIAS
}

POR

\author{
Alejandro García Álvarez-Busto* y Noelia Fernández Calderón**
}

\section{RESUMEN - ABSTRACT}

En este artículo se analizan unos acicates de hierro dorados recuperados en el enterramiento de un caballero del siglo XIII en el monasterio de Corias (Asturias). En primer lugar se expone una valoración del contexto estratigráfico y una descripción de las piezas; en una segunda parte se establece la cronología de los acicates a partir del análisis comparativo con otros ejemplos recuperados en los diferentes reinos de la península ibérica; y finalmente se lleva a cabo una contextualización política y socioeconómica del orden de los caballeros en la Asturias del siglo XIII.

In this paper we analyze some iron spurs gold recovered in the burial of a knight of the thirteenth century in the monastery of Corias (Asturias, Spain) First, it exposes a stratigraphic context assessment and a description of the spurs; in a second part establishes the chronology of the spurs from comparative analysis with other examples recovered in the different kingdoms of the Iberian Peninsula; and finally performs a socioeconomic and political contextualization of the order of knights in Asturias in the thirteenth century.

\section{Palabras Clave - Keywords}

Acicates; nobleza; caballero; enterramiento; monasterio; Asturias; Edad Media.

Spurs; nobility; knight; burial; monastery; Asturias; Middle Ages.

\section{INTRODUCCIÓN ${ }^{* * *}$}

La arqueología medieval es todavía una ciencia joven en Asturias, desde que protagonizara su primer impulso científico en los años ochenta del pasado siglo. A partir de entonces han proliferado las excavaciones arqueológicas de cementerios en monasterios e iglesias parroquiales, y por primera vez se ha podido documentar en nuestra región un enterramiento medieval

\footnotetext{
* Área de Arqueología. Departamento de Historia. Universidad de Oviedo. Oviedo, garciaalejandro@uniovi.es.

** Arqueóloga. Licenciada en Historia, Universidad de Oviedo. Diplomada en Conservación-restauración de Bienes Culturales, Escuela Superior de Artes del Principado de Asturias, noefernandez@gmail.com.

${ }^{* * *}$ Los autores de este artículo queremos expresar nuestro agradecimiento a Mikel Neira Zubieta por la información inédita proporcionada sobre los acicates del castillo de Ereñozar; y a Jesús Antonio González Calle, doctor en Historia, y a los evaluadores del manuscrito, por sus aportaciones y sugerencias al texto.
} 
perteneciente a un caballero que conservaba sus espuelas calzadas ${ }^{1}$. Se trata concretamente de unos acicates, que es como se denomina a las espuelas con punta, y que en el Poema de Mio Cid recibían el elocuente sobrenombre de "agudas" (Marreno Cabrera, 1998: 169).

La documentación de este enterramiento nobiliario tuvo lugar en el año 2010 durante el seguimiento arqueológico de las obras de reconversión del edificio monástico en parador de turismo ${ }^{2}$. El monasterio benedictino de San Juan Bautista de Corias fue fundado en 1043 por los condes Piñolo Jiménez y Aldonza Muñoz, cuando es consagrada su iglesia fundacional. Ya en el siglo XII, concretamente en 1113, tendrá lugar la consagración de una nueva iglesia monástica más capaz, pasando a partir de entonces la iglesia fundacional a funcionar como capilla cementerial de carácter aristocrático (García Álvarez-Busto 2012a: 150).

El uso funerario de esta capilla, dedicada a Santa María, está bien documentado en el periodo bajomedieval tanto arqueológicamente como a través del registro escrito. Así, el libro de aniversarios del monasterio, redactado en la segunda mitad del siglo XIV, recopila las misas dedicadas al nutrido elenco de representantes de la aristocracia comarcal que escogieron esta capilla como lugar de enterramiento, a cambio, eso sí, de la entrega de copiosas donaciones pro anima. El templo actuaba como centro funerario de prestigio, albergando en su interior poderosos imanes: el panteón de los condes fundadores, los sepulcros de buena parte de las abades corienses, y la tumba del rey Bermudo y su esposa, esta última una más que probable inventio por parte de la comunidad monástica con el objetivo de ensalzar aún más sus orígenes.

Por su parte la excavación arqueológica ha permitido documentar el intenso uso funerario que se hizo del interior de esta capilla entre los siglos XIII y XVII, documentándose un total de 45 enterramientos y numerosos osarios generados por la superposición de inhumaciones. La nave es el espacio interior que presenta mayor densidad de enterramientos, disminuyendo

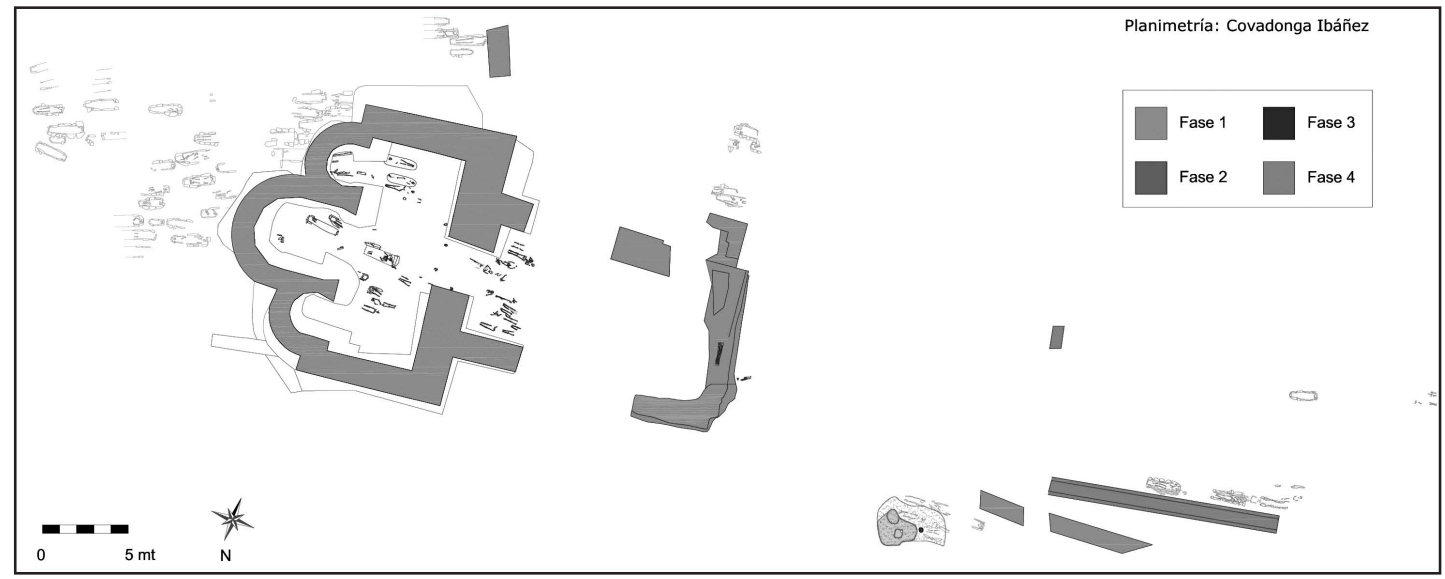

Figura 1. Planta de la iglesia fundacional del monasterio de Corias, consagrada en 1043, y reconvertida en capilla funeraria de Santa María en la Baja Edad Media. Fase 1: siglo XI. Fase 2: siglo XII. Fase 3: siglos XIII-XIV. Fase 4: siglo XV.

1 Hasta la fecha solo se habían documentado en Asturias dos acicates medievales sueltos, no emparejados, y no en contexto funerario sino militar. Nos estamos refiriendo al acicate recuperado en el castillo de Gauzón, con una cronología de los siglos XII-XIII (Muñiz y García, 2010: 112); y al acicate localizado en la muralla lineal de El Muro en el cordal de La Mesa, fechado por sus descubridores entre los siglos XII y XIV (Camino, Viniegra y Estrada, 2013: 292).

2 La elaboración de este artículo no habría sido posible sin el espléndido trabajo realizado por el equipo de arqueólogos que participaron en la excavación arqueológica, formado por Alejandro Sánchez Díaz, Covadonga Ibáñez Calzada, Francisco X. Fernández Riestra, David Flórez de la Sierra y Alberto Morán Corte. 
su número en el transepto y en los ábsides de la triple cabecera. En cuanto a su morfología se constatan tanto tumbas de lajas como inhumaciones en fosa, y junto a algunos de los esqueletos se han recuperados ajuares y objetos de adorno, entre los que cabe destacar monedas, alfileres, clavos-tachones de ataúd, unos segundos acicates fragmentados, una hebilla de cinturón y una contera de puñal. Las características de estos depósitos funerarios reflejan el uso cementerial de la nave de la capilla por parte del estamento nobiliario comarcal, mientras que los abades solían ubicarse en arcosolios abiertos en los muros del templo. Por el contrario en el exterior de la cabecera de esta iglesia fundacional se documentó un cementerio de tumbas de lajas, vinculado probablemente a las familias de siervos dependientes del monasterio (García Álvarez-Busto, 2012b: 170-74) (fig. 1).

\section{EL ENTERRAMIENTO NOBILIARIO Y LOS ACICATES. CONTEXTO ARQUEOLÓGICO.}

A diferencia del transepto sur, donde se localizaron cuatro inhumaciones en fosa, en el transepto norte tan solo se identificó un enterramiento, aunque éste, como veremos, presentaba un carácter privilegiado.

La estratigrafía documentada en el subsuelo del transepto es parecida en el brazo sur y en el norte. A nivel de suelo, y bajo los arrasamientos producidos tras el incendio de 1763, se conserva un pavimento de ladrillos sobre preparado de mortero. Por debajo nos encontramos con un relleno de tierra en el que se recuperó algún fragmento de hueso suelto, aunque en menor número que en el transepto sur.

A una profundidad de $40-45 \mathrm{~cm}$ con respecto al pavimento se localizó un enterramiento (U.E. 2-22) en posición de decúbito supino con los pies dispuestos hacia el este. El individuo presentaba un irregular estado de conservación, habiendo sido removida la mitad superior del tronco y del cráneo, aunque sobre las vértebras lumbares aún conservaba parcialmente el antebrazo derecho.

El esqueleto se encontraba depositado en una fosa de inhumación, no diferenciándose claramente su contorno del relleno de tierra que contenía, y únicamente en la zona de los pies se pudieron diferenciar unas finas capas de cal asociadas a los huesos. Como elemento singular hay que destacar que el individuo se encontraba calzado con dos acicates que presentaban las puntas enfrentadas, recuperándose además fragmentos de cuero en los dos pies y que probablemente perteneciesen a su calzado (fig. 2-3).

Los acicates están elaborados en hierro forjado recubierto de oro mediante la técnica del dorado al mercurio. Cada pieza tiene una punta cónica de sección redonda, curvada hacia abajo en un ángulo cercano a los $45^{\circ}$ respecto a la caja, y con un tope esférico. Presentan una caja con ramas de sección oblonga curvadas en ángulo de $65^{\circ}$, siendo más estrechas en los laterales, de tal forma que alcanzan su mayor anchura en la zona central donde se forma el ángulo de curvatura. Ambos terminales tienen un solo orificio.

El terminal de la rama interna se compone de una lámina plegada y soldada que origina un orificio rectangular alargado. La rama exterior presenta también un cierre anular, en este caso circular, del que pende una hebilla de bronce. Dicha hebilla se une al terminal mediante un remache cuadrangular broncíneo, decorado con una roseta de seis pétalos en relieve. Su forma es ligeramente ovalada, de sección redonda, y con un pequeño apéndice o engrosamiento en la zona donde apoya el hebijón, realizado en hierro. Bajo la hebilla se sitúa, en perpendicular a la caja, otro pequeño remache broncíneo con forma de lámina rectangular. De esta manera los terminales se unirían entre sí sobre el puente del pie (hebilla) y bajo el empeine (trabillaremache rectangular) mediante dos cintas de cuero, seda o lino. 


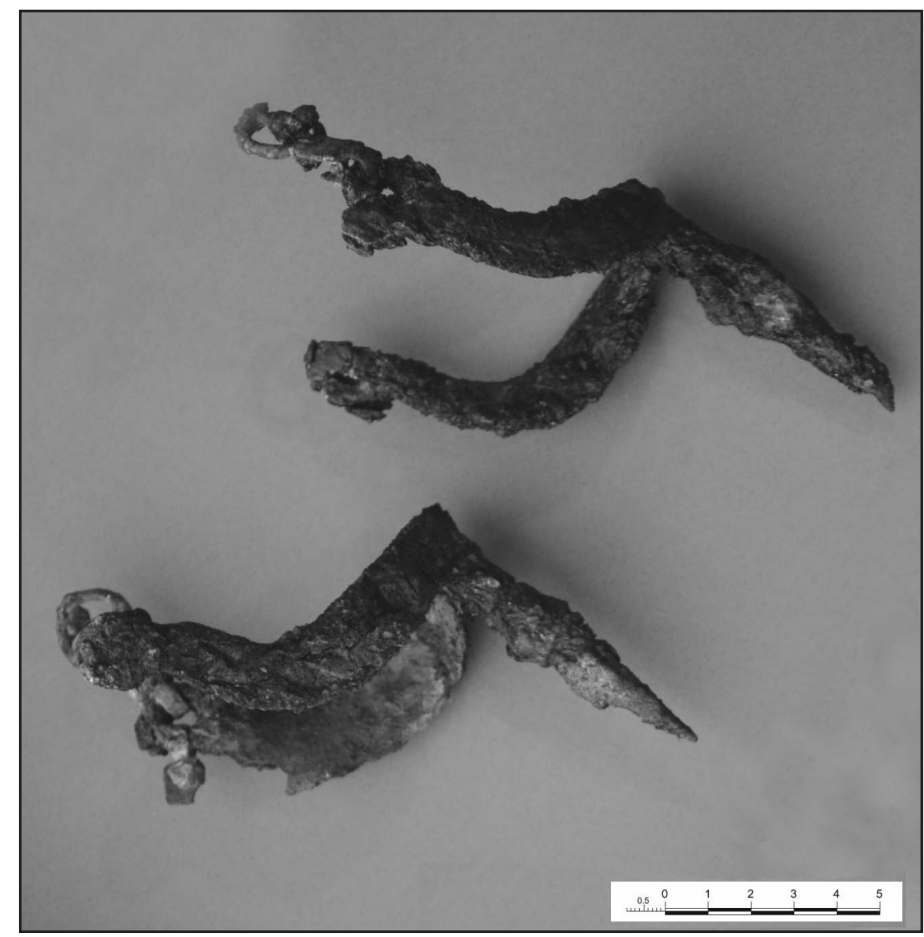

Figura 2. Acicates recuperados en el enterramiento del caballero del transepto norte.

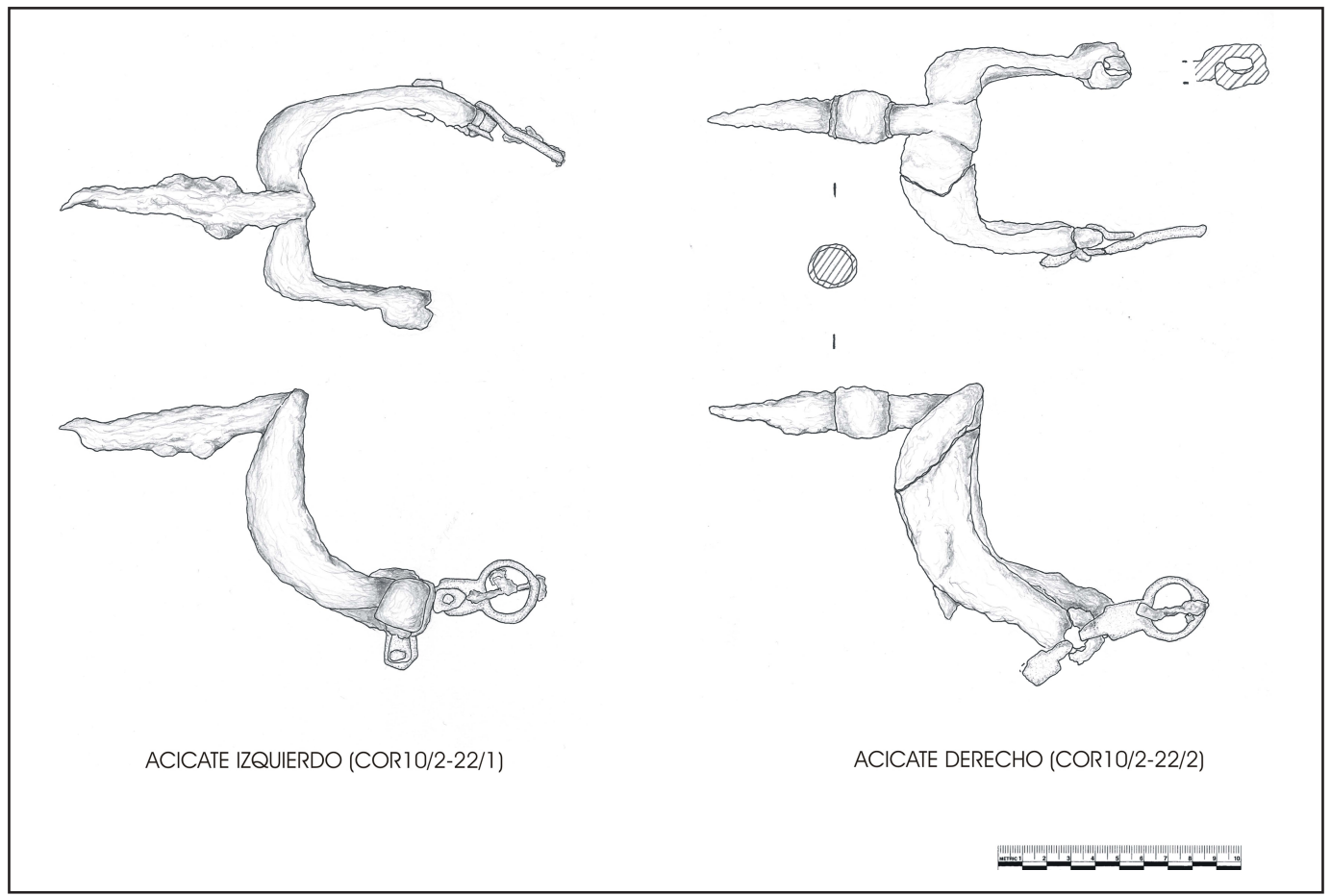

Figura 3. Dibujo de los acicates recuperados en el enterramiento del caballero del transepto norte. 

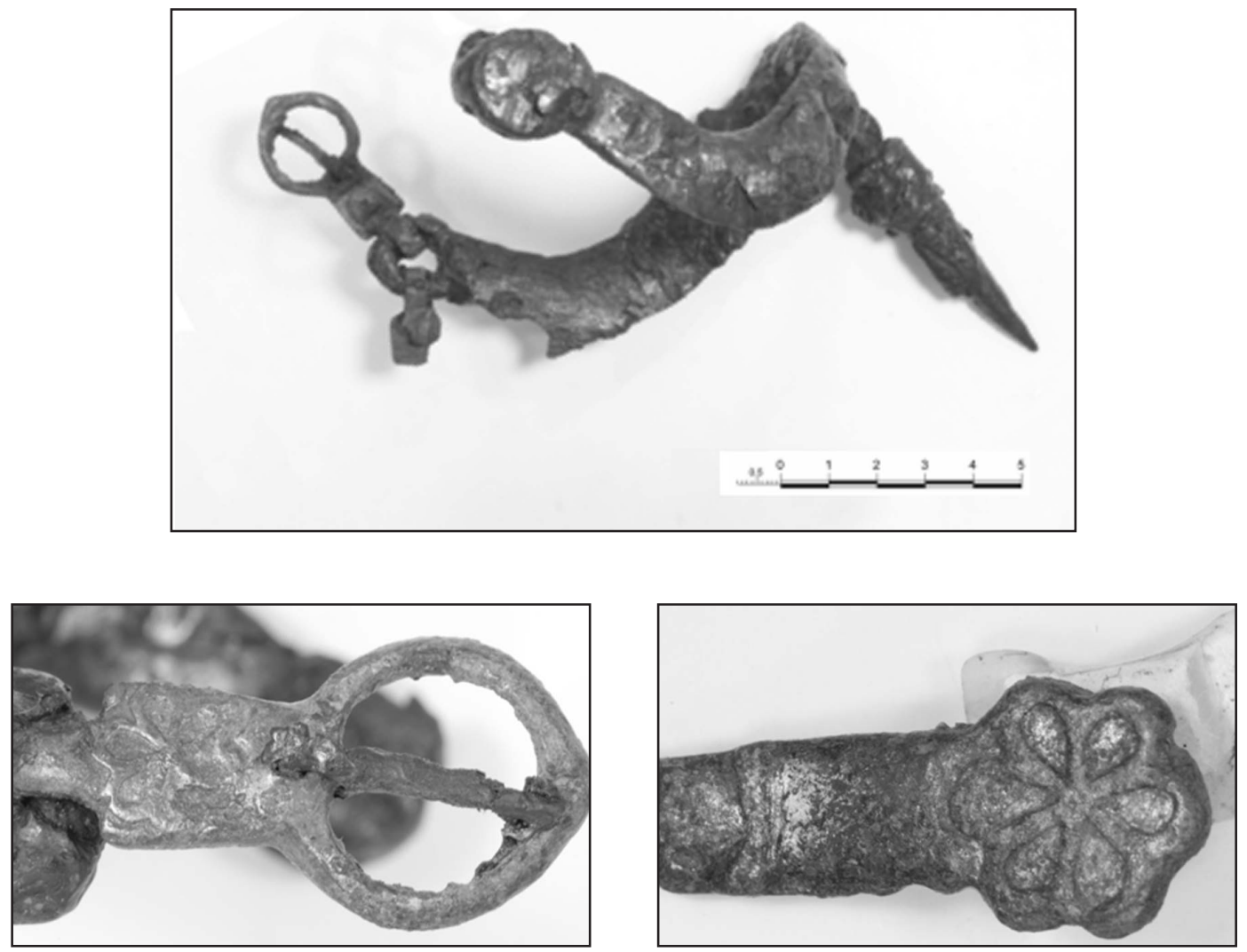

Figura 4. Fotografía y detalles de los acicates una vez completados los trabajos de limpieza y conservación (Foto: Beatriz García Alonso).

El conjunto de acicates se complementa con un pequeño pinjante que repite la misma decoración del remache de la hebilla, una roseta de seis pétalos de la que parte una lámina fusiforme que imita una hoja estilizada (fig. 4).

Junto a este par de acicates en Corias se ha hallado otro de similares características, también de hierro forjado y dorado al mercurio, tratándose de un trozo de la punta con tope esférico que únicamente conserva la zona posterior de la caja, y un fragmento inconexo de una de las ramas (fig. 5).

Además, en el mismo contexto estratigráfico — enterramientos de la nave - se recuperaron una hebilla de cinturón de bronce y una contera de funda de puñal elaborada en plata. La hebilla broncínea presenta forma oval con sección aplanada y rebaje en la zona de apoyo de la aguja, con pasador recto de sección circular y decoración con líneas incisas en zig-zag. Por su parte la contera tiene forma cónica con tope esférico, y está decorada en el anverso con un escudo apuntado como emblema heráldico³ (figs. 6 y 7).

3 Tanto la hebilla como la contera fueron recuperadas en el mismo contexto estratigráfico-funerario que los acicates, por tanto con un cronología de los siglos XIII y XIV. La contera de plata decorada con el escudo nos sitúa en la órbita de otro enterramiento de carácter nobiliario, teniendo en cuenta además que durante el primer tercio del siglo XIII el conjunto de la nobleza adoptará el uso de los emblemas heráldicos como representación del linaje, una práctica que se consolidará a lo largo de la centuria. Vid. al respecto Ceballos-Escalera, 2010. En esta misma línea hace tiempo que Sánchez Ameijeiras (1989: 433) puso de manifiesto la costumbre de reflejar las armas del caballero en los pomos de las espadas. 


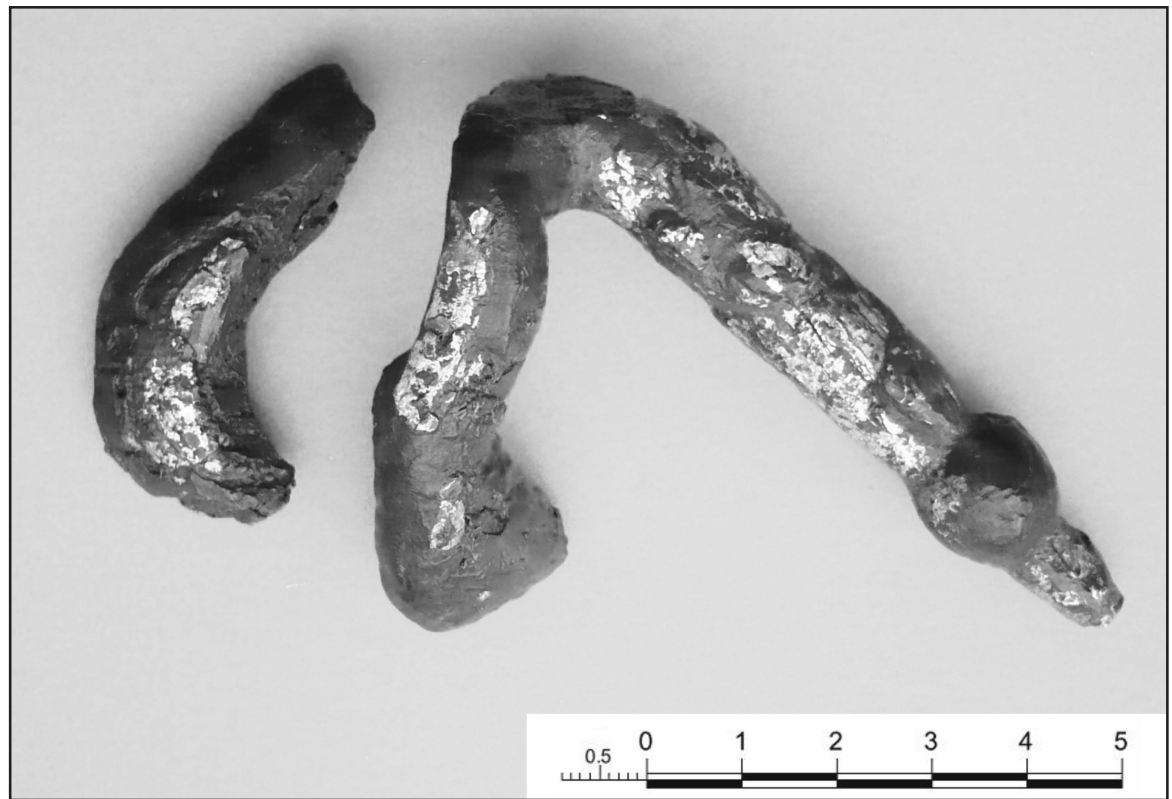

Figura 5. Fragmentos del castigo, la caja y la rama de un tercer acicate recuperado en el nivel inferior de enterramientos de la nave de la capilla de Santa María.

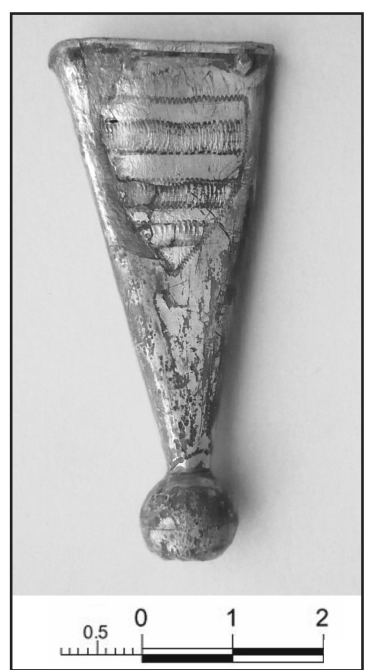

Figura 6. Contera de funda de puñal elaborada en plata, con tope esférico y escudo apuntado.

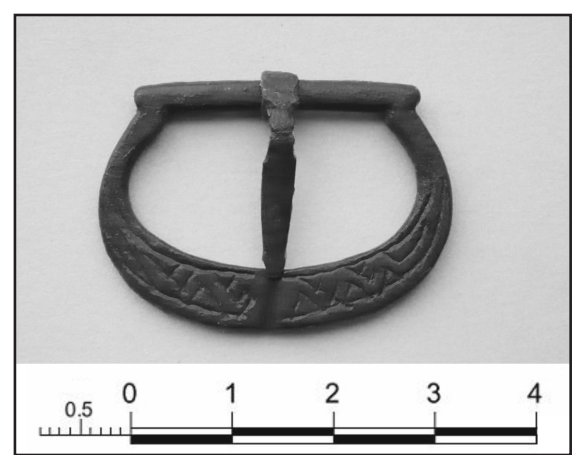

Figura 7. Hebilla de bronce decorada con líneas incisas en zig-zag.

\section{LOS ACICATES. ANÁLISIS COMPARATIVO Y CONTEXTO CRONOLÓGICO}

Ante la falta de dataciones radiométricas la cronología de los acicates documentados en Corias se puede establecer a partir del análisis comparativo con otros yacimientos arqueológicos en los que también se han recuperado esta tipología de espuelas.

De esta manera algunos de los referentes más cercanos los encontramos en un conjunto de cinco acicates procedentes de la capilla del Espíritu Santo de la catedral de Tudela, que presentan idénticas características morfológicas (ramas curvas, punta de gran longitud con tope 


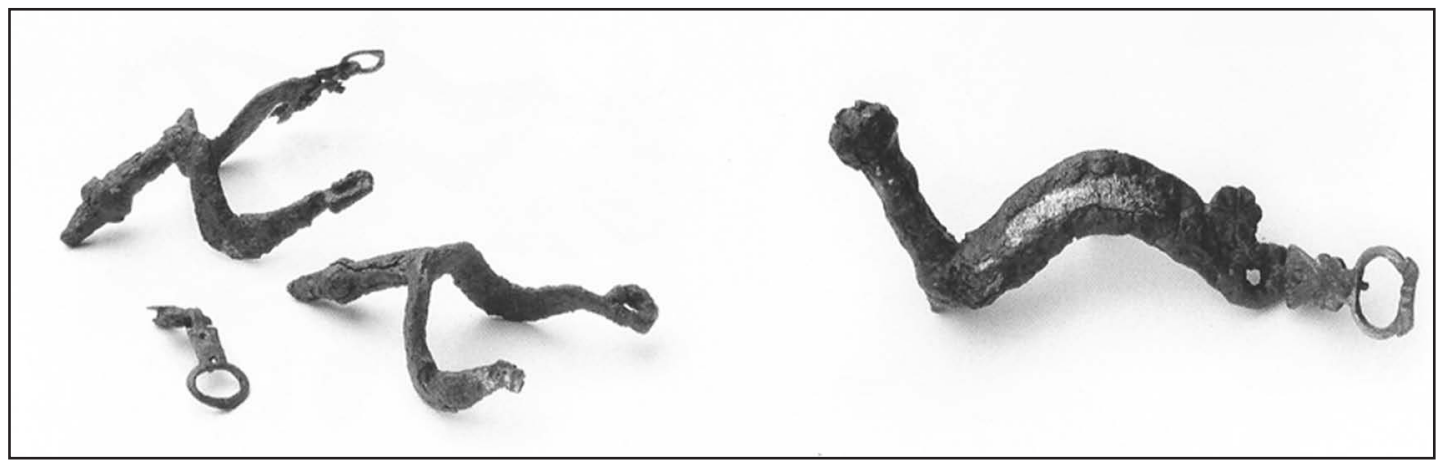

Figura 8. Acicates de hierro forjado y dorado encontrados en dos de los enterramientos localizados en la sacristía del Espíritu Santo de la catedral de Tudela (s. XIII - comienzos del XIV)(AA.VV, 2006).

esférico y terminales de un solo orificio), decorativas (remache del broche con decoración) y técnicas (hierro forjado bañado en oro). Las fechas que se barajan para este conjunto son de finales del siglo XIII principios del XIV (AA.VV, 2006: 163) (fig. 8)

Por su parte en el País Vasco se han recuperado dos acicates en el cementerio del castillo de Ereñozar (Vizcaya), datados también en el siglo XIII y que presentan los mismos rasgos que los ejemplos encontrados en la catedral navarra ${ }^{4}$.

Otros acicates dorados, aunque ligeramente diferentes en su morfología, fueron localizados en un enterramiento del cementerio situado en el exterior de la cabecera de la colegiata de San Prudencio de Armentia (Vitoria-Gasteiz). La inhumación se fecha entre la segunda mitad del siglo XII y el siglo XIII (López Sebastián, 2008). Su morfología se acerca a ejemplos más tempranos, con punta de menor longitud rematada en un tope cónico. Además, dada la rica decoración que presentan nos encontramos ante unos acicates de carácter ceremonial, vinculados a la muerte del caballero como ajuar funerario que refleja un estatus social. También asumirían una función ceremonial en el acto de armar caballeros, tal como se apunta respecto a los acicates encontrados en un enterramiento en el claustro de la colegiata de San Martín de Elines (Cantabria) fechado en el siglo XIII (Soler del Campo, 2007: 221).

En el cementerio de Santa María de Siones (Burgos) se recuperó un acicate de hierro, latón y plata sobredorada. Esta tipología, con caja curva y punta inclinada en ángulo de $45^{\circ}$ respecto a la caja, tiene antecedentes en el siglo XII aunque su periodo de mayor difusión es la segunda mitad del XIII, perviviendo en la iconografía castellana de la primera parte del siglo XIV. Los roleos y palmetas que decoran las hebillas desvelan su procedencia hispana ( $I b: 222)$.

Son similares a los acicates de Fernando de la Cerda, del tercer cuarto del siglo XIII, en cuanto a la presencia de un tope esférico a mitad de la punta, aunque el desarrollo de éstos es más corto; pero sobre todo a los de Fernando III, datados entre 1217 y $1230^{5}$, presentando rasgos semejantes en la curvatura de la caja, la punta muy desarrollada, y la hebilla y ambos terminales con un solo orificio (fig.9).

4 Información inédita facilitada por Mikel Neira Zubieta, director de las excavaciones arqueológicas en el castillo de Ereñozar, promocionadas por el Departamento de Cultura de la Diputación Foral de Bizkaia

5 Soler del Campo, 2007, 219. Los acicates formaban parte del ajuar de la tumba de Fernando III. Se sabe que la tumba fue abierta en los siglos XVI y XVIII y los acicates fueron depositados en el Alcázar de Madrid en el siglo XVII, para ser llevados posteriormente a la Capilla Real y finalmente en el siglo XVIII se trasladaron a la Real Armería. La cronología viene dada por la decoración de castillos que presenta en toda su superficie, lo que hace suponer que fueron elaboradas entre su coronación como rey de Castilla (1217) y la unión con el reino de León (1230). 

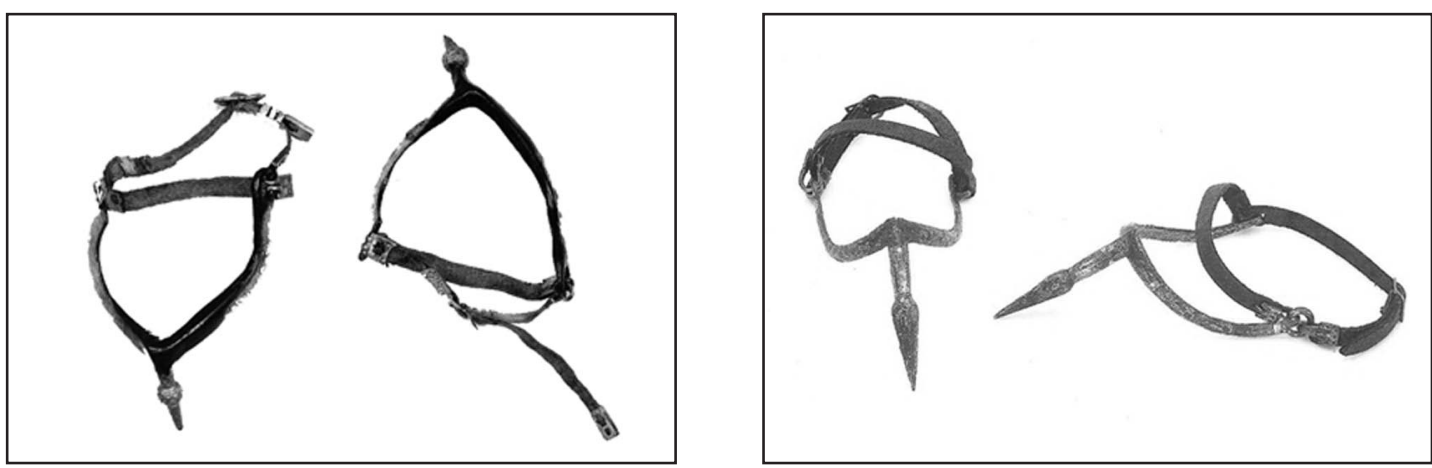

Figura 9. de Fernando de la Cerda (izquierda) y de Fernando III (derecha) Elorza Guinea, 2007.

En Portugal también se han identificado varios ejemplos con fisonomías análogas, como el conjunto de cuatro espuelas procedente de dos enterramientos situados en la nave de la iglesia del convento de San Salvador de Vilar de Frades (Braga), y datado entre los siglos XIII y XV (Erasun Cortés y Monteiro Faure, 2008-2009). Se asemejan a las de Corias en varios aspectos: las dos primeras, fechadas en el XIII, tienen el mismo tipo de terminales y caja curvada; mientras que las del siglo XV son las más emparentadas en cuanto a su morfología general: caja curva, terminales de un solo orificio y punta cónica con tope.

Una de las singularidades que tienen los acicates de Corias con respecto al resto de paralelos manejados es la forma de sus topes, que presentan dos pequeñas molduras que enmascaran

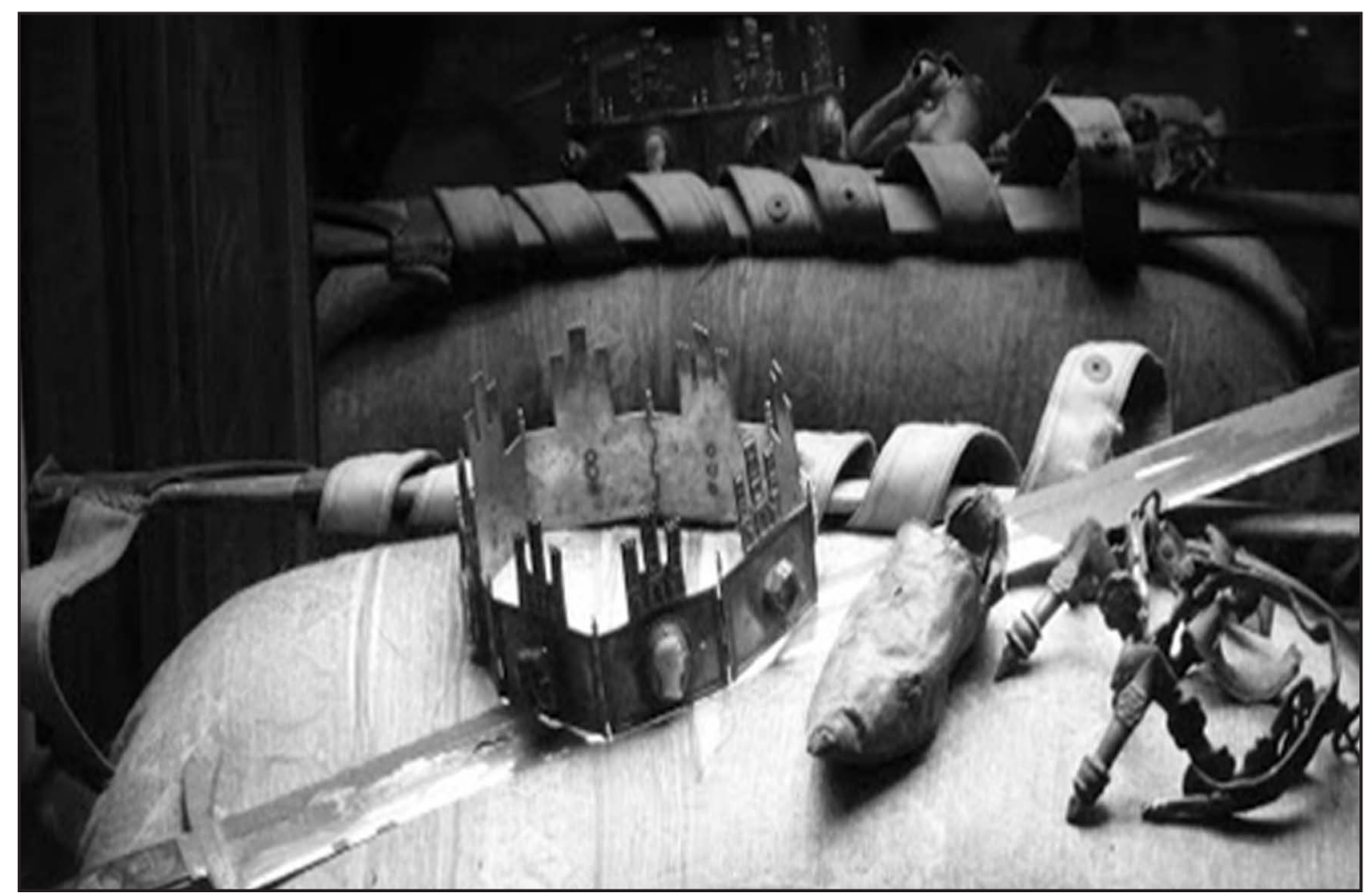

Figura 10. Ajuar funerario de Sancho IV de Castilla. Catedral de Toledo. 
su forma esférica y que sirven además de elemento ornamental. Esta disposición la encontramos también en los acicates hallados en la tumba del rey Sancho IV de Castilla ${ }^{6}$, de finales del siglo XIII (fig. 10), y en una de las espuelas del conjunto de Vilar de Frades (Portugal), datada en el siglo $\mathrm{XV}^{7}$.

Como se puede apreciar a partir de esta revisión el registro arqueológico enmarca este tipo de acicates en el siglo XIII, aunque perdurando en el siguiente; una cronología que se refuerza si ampliamos la perspectiva del análisis con otras fuentes de información complementarias como la miniatura, la escultura arquitectónica o el arte funerario de los sepulcros.

De esta manera esta tipología concreta de espuelas aparece reflejada en la representación de Fernando III del Tumbo A de Santiago de Compostela o en la Cantigas de Santa María de Alfonso X (fig. 11). También en la decoración escultórica de los capiteles de la iglesia románica de San Juan de Amandi (Asturias), fechada en el primer tercio del siglo XIII, y donde

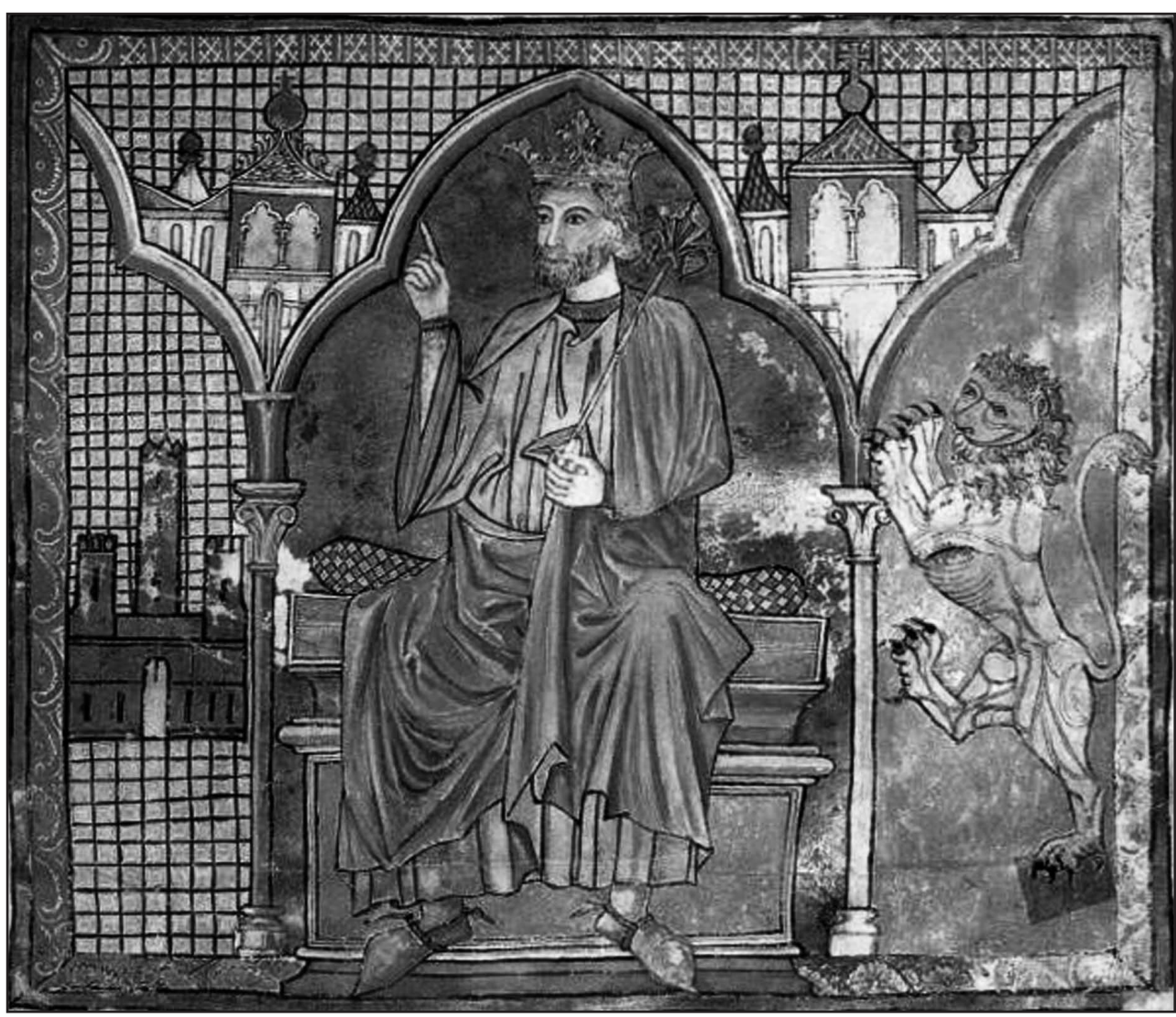

Figura 11. Representación de Fernando III en el Tumbo A de Santiago de Compostela (Yzquierdo, 2012).

6 En 1948, a petición del gobierno portugués, se lleva a cabo la búsqueda de la tumba de Sancho II de Portugal en la Capilla Real de la Catedral de Toledo (Blair, 1959: 41). En el transcurso de dichos trabajos se exhuman los restos de Sancho IV de Castilla, recuperando del interior de su tumba las espuelas, junto con la corona, la espada y el calzado que actualmente se exponen en la Sacristía Mayor de la Catedral.

Número de inventario: VF99/30/23/17, A20 e A21 (Erasun Cortés y Monteiro Faure, 2008-2009: 192, fig. 9) 


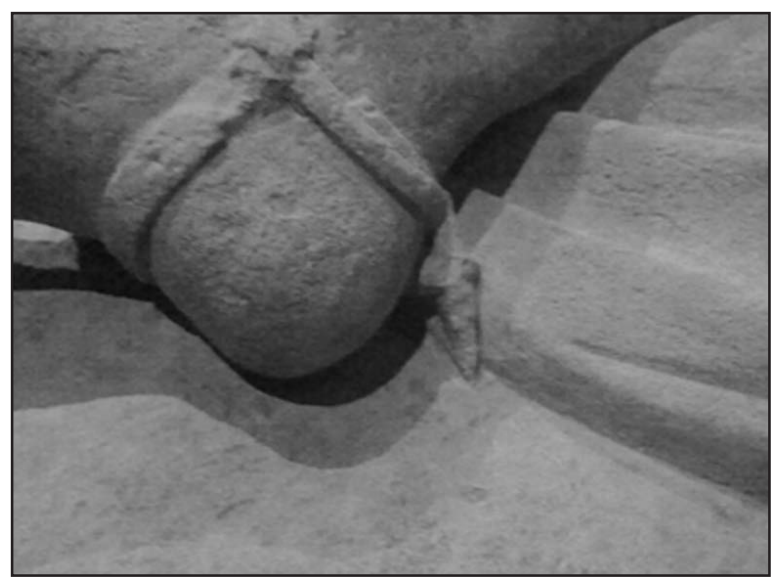

Figura 12. Acicate en sepulcro de caballero de los Téllez de Meneses. circa 1300.

se representa un torneo con dos caballeros enfrentados que calzan acicates de una sola punta (Friera y Álvarez, 1984: 227; Álvarez Martínez, 1999: 168).

Con respecto a su representación en el arte funerario unos acicates de similar morfología aparecen en el sepulcro de un caballero de la familia de los Téllez de Meneses, fechado hacia 1300 y que se encontraba en el monasterio cisterciense de Santa María de Matallana (Valladolid) ${ }^{8}$ (fig. 12), o en el del rey Sancho VII de Navarra en la Colegiata de Roncesvalles (Navarra), del primer tercio del siglo XIII. Casi un siglo posterior es el sepulcro de Don Fernán Pérez de Andrade en la iglesia de San Francisco de Betanzos, y que también presenta el mismo tipo de acicate (Manso Porto, 1989), ilustrando la perduración de esta tipología a lo largo del siglo XIV (fig. 13).

En síntesis, y como se ha podido comprobar a partir del análisis comparativo, la cronología del enterramiento nobiliario excavado en Corias no ofrece demasiadas dudas, ya que

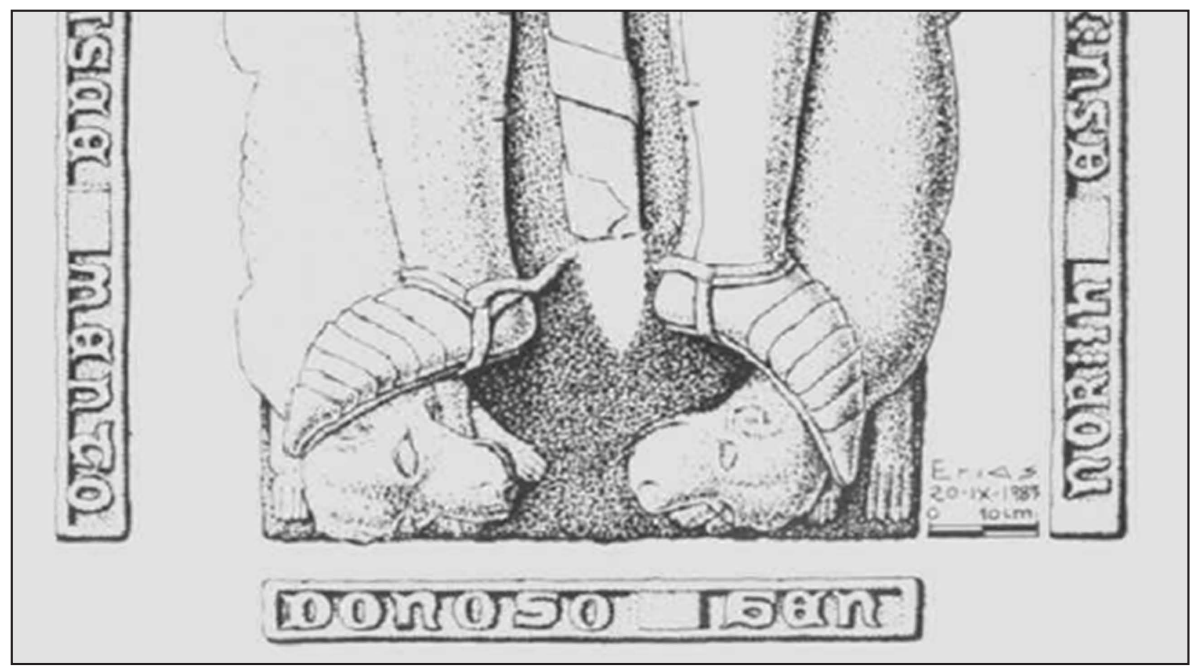

Figura 13. Detalle del sepulcro de Fernán Pérez de Andrade (Manso Porto, 1989).

8 El sepulcro se conserva en la actualidad en el MNAC 
esta tipología de acicates nos remite fundamentalmente al siglo XIII, prolongándose hasta la centuria siguiente, cuando empezará a ser gradualmente sustituida por las espuelas de rueda9 . En cuanto a su morfología, será a partir del siglo XII cuando comienza a aumentar la longitud de la punta de los acicates y los terminales pasen a tener un solo orificio (García Cuadrado, 1993: 336); mientras que la acusada curvatura que muestran las ramas es una característica que aparece en la siguiente centuria. Ésta es una más de las particularidades que llevan a datar los acicates de Corias en el siglo XIII, periodo en el que además las ramas muestran una carena muy pronunciada, provocando la consiguiente torsión en diagonal de la punta. Esta inflexión tan remarcada permitía encajar en ellas la parte inferior de las grebas ${ }^{10}$ (fig. 14).

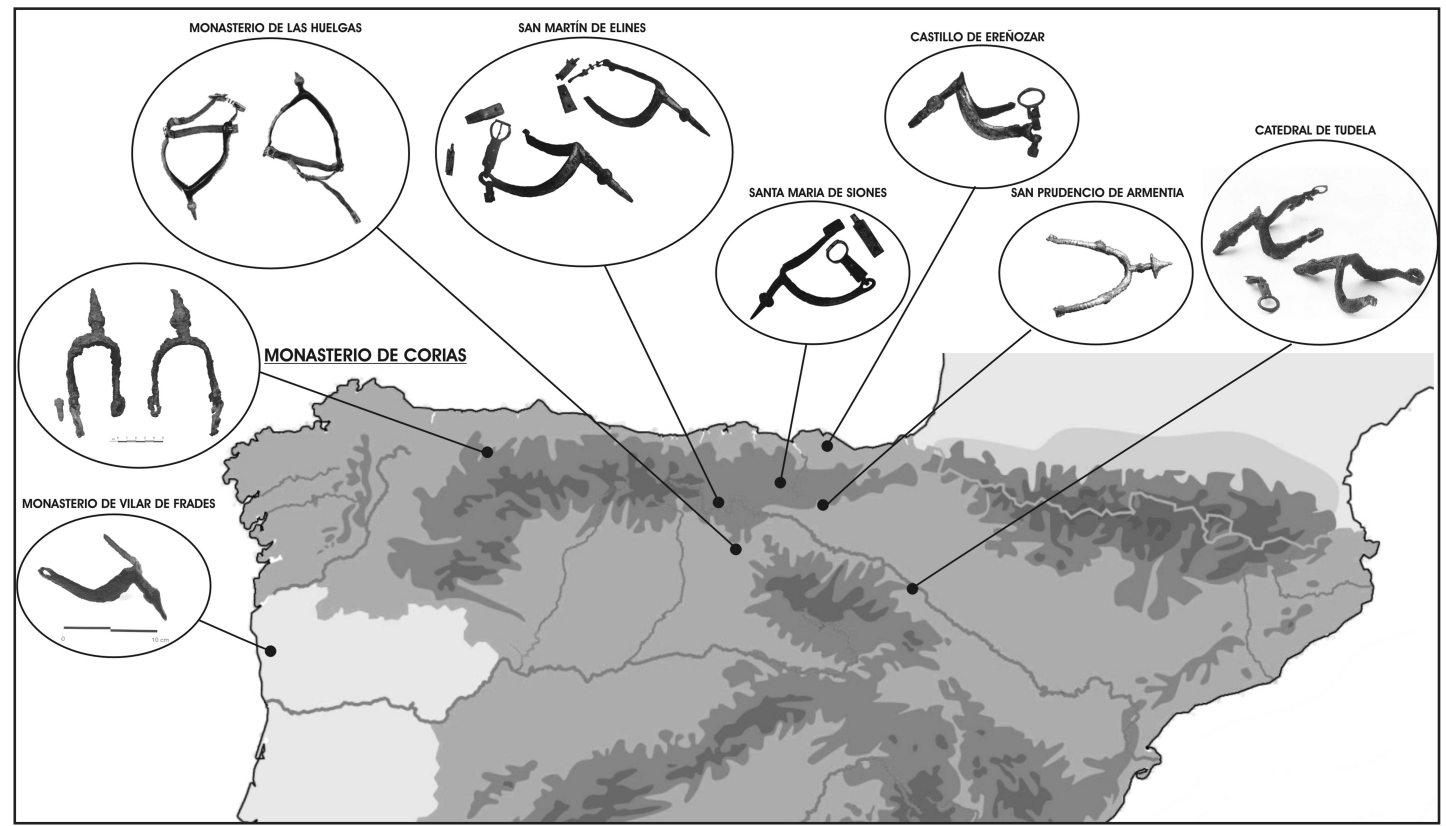

Figura 14. Localización geográfica de los acicates estudiados en el texto.

\section{EL CABALLERO DE LAS ESPUELAS DORADAS. CONTEXTO SOCIAL}

Los siglos XII, XIII y XIV, los siglos centrales del Medievo, conocieron la implosión de la figura del caballero, y ya de hecho Duby identificaba la decimosegunda centuria en Francia con el siglo de los caballeros. El estudio de sus orígenes y su significado social ha constituido un tema recurrente de la historiografía medieval en Francia, Inglaterra, Aragón o Castilla,

9 Concretamente esta tipología de espuelas de rueda comienza a adoptarse tanto en la península ibérica como en los diferentes reinos del occidente europeo a partir de mediados del siglo XIII. En la península conocemos ejemplos tempranos de este nuevo tipo como el procedente de El Campillo (Vitoria), fechada entre 1250 y 1300 (Soler del Campo, 2007: 226).

10 Soler del Campo, 1987,180 y ss. Si bien las estrategias bélicas determinan el uso del acicate, los cambios en las armaduras también condicionan su forma, de ahí que la generalización del uso de las grebas en el siglo XIII provoque un cambio en la morfología de los acicates. Los acicates son utilizados profusamente desde la Alta Edad Media por su carácter polivalente en la monta a caballo. Pese a que son más eficaces en la caballería ligera a la jineta también serán empleados en la caballería pesada a la brida, aunque con un uso secundario respecto a la espuela de rueda, más eficaz en este último tipo de carga. 
aunque a una escala menor, centrándonos en el territorio asturiano, y desde una perspectiva socioeconómica, no es mucho lo que sabemos sobre estos señores de armas en el siglo XIII, cuando fue enterrado en el monasterio de Corias el caballero de las espuelas doradas ${ }^{11}$.

La arqueología de sus viviendas o de la cultura material que ostentaban es todavía muy débil y apenas nos ofrece información con respecto a su caracterización política, social o económica, la cual se tiene que trazar por el momento, y en exclusiva, a partir de una escasa documentación escrita que será mucho más rica en las siguientes centurias, sobremanera al contar con los testamentos de los siglos XIV y XV.

En el registro textual esta nobleza rural aparece tempranamente mencionada en el Fuero de Oviedo (1145), en el que se "distingue el servicio armado del caballero del prestado por el peón, al regular la obligación que los vecinos de la ciudad tenían de acudir al fonsado" (Ruiz de la Peña, 1977: 201). Son los milites, habituales en la documentación de la decimosegunda centuria, y que también aparecerán representados entre los grupos de poder de la ciudad de Oviedo $^{12}$. Por regla general su éxito y consolidación social serán auspiciados por sus servicios a la monarquía ${ }^{13}$, que a su vez les recompensaba con tenencias territoriales en las que ejercían como sus representantes ${ }^{14}$. Este comportamiento no era ni mucho menos exclusivo del rey, sino que los mismos obispos de Oviedo entregaban a esta nobleza regional el control de sus castillos y encomiendas episcopales ${ }^{15}$. Por otra parte en el siglo XIII empieza a constituirse con mayor fuerza una conciencia de linaje ${ }^{16}$, y parece que será también ahora cuando se consolide el empleo de los apellidos locativos por parte de estas familias nobiliarias ${ }^{17}$.

En cualquier caso es muy poco lo que conocemos sobre la distribución de la propiedad agraria de estos caballeros ${ }^{18}$, y menos aún sobre los mecanismos que regían su explotación o sobre su relación con el campesinado ${ }^{19}$. Lo que sí se sabe es que mantenían vínculos con los

11 Sin embargo para la centuria anterior sí que contamos con estudios monográficos sobre la aristocracia astur, como el dedicado por M. Calleja Puerta (2001) al conde Suero Vermúdez y su parentela, o el de I. Muñiz López (2008) a la familia de los Enalso. Para los siglos XIII, XIV y XV el estudio de referencia es la tesis doctoral de J. A. González Calle (2001) La nobleza en Asturias durante la Baja Edad Media: génesis y evolución de linajes representativos, que se encuentra inédita.

12 Como en la ceremonia que tuvo lugar en 1200 en el capítulo de San Vicente "ante canonicos et burgueses et cavalleros et monges" (Ruiz de la Peña, 1977: 201).

13 Un magnífico ejemplo lo constituyen Alvar Díaz, del que sabemos que en 1199 además de ostentar la tenencia regia del territorio de Aguilar fue uno de los doce caballeros escogidos por Alfonso IX para velar por la dote que el monarca había otorgado a su esposa doña Berenguela; y su hijo Ordoño Álvarez, uno de los caballeros encargados en 1230 de vigilar el cumplimiento del tratado establecido entre Fernando III y sus hermanas (Fernández Suárez, 1996: 247-250).

14 Entre la segunda mitad del siglo XII y la primera del XIII se aprecia una mayor movilidad en la titularidad de las tenencias reales frente al periodo anterior - más dominado por las familias condales - y teniendo lugar ahora una mayor accesibilidad a estos cargos por parte de los caballeros y otros miembros de la nobleza local asturiana (Jular Pérez-Alfaro, 1990: 65-68; García Álvarez-Busto y Muñiz López, 2005: 114-18).

15 Es el caso del caballero Rodrigo Álvarez de Solís, del que sabemos sabemos que hacia 1289 disfrutaba de la encomienda del territorio de Llanera de la mano del obispo de Oviedo (González Calle, 2011: 126-127); y de los primeros representantes del linaje de los Bernaldo, que en el siglo XIII detentaban las encomiendas episcopales de Teverga (Fernández Suárez, 1995: 156).

16 Que no se documenta tan claramente en la centuria anterior, tal y como ha estudiado M. Calleja Puerta (2001: 155-156).

17 Es en el siglo XIII cuando en el noroeste peninsular se consolidan los linajes nobiliarios de carácter vertical, superando la estructura horizontal de parentesco aristocrático que caracteriza las centurias anteriores (Beceiro Pita y Córdoba de la Llave, 1990). En este sentido parece existir cierto retraso con respecto a otros reinos europeos o el propio nordeste hispánico en el proceso de consolidación del linaje en el que se favorece a uno de los vástagos, tal y como ha definido P. Martínez Sopena (2008) a partir del análisis de la antroponimia locativa. Para el caso asturiano resulta representativo el linaje de los Valdés, apreciándose como en el siglo XIII se consolida el empleo de su apelativo locativo (González Calle, 2012: 28-29).

18 Destacan en esta línea los trabajos realizados por J. A. González Calle (2002 y 2011), especialmente los capítulos dedicados al análisis del patrimonio de los Escamprero y los Areces.

19 Conocemos casos como el del caballero Pedro Martínez de Pillarno, quien en 1260 entregaba como arras a su mujer un tercio de las heredades que tenía en seis aldeas diferentes, y que pertenecería al grupo de propietarios de cierta entidad (García Álvarez-Busto y Muñiz López, 2005: 356); pero también existían otros pequeños nobles rurales de con- 
monasterios, la mitra y otros grandes señoríos, como meros arrendadores en algunos casos y con estrechos vínculos clientelares en otros. De hecho esta caballería constituía la mano armada tanto de la alta nobleza laica como de los obispos y abades, y como malfechores aparecerán descritos en aquellos documentos que recogen los enfrentamientos y la tensión habida entre los señores feudales y los concejos urbanos durante el periodo bajomedieval asturiano ${ }^{20}$.

Por su parte la investigación arqueológica sensu stricto nos ofrece muy poco hasta la fecha a la hora de caracterizar el estatus que ostentaban estos caballeros en la sociedad asturiana del temprano bajomedievo. Sabemos que en el siglo XIII algunas de las grandes fortificaciones altomedievales continuaban ocupadas por ellos ${ }^{21}$, y también se empieza a intuir que las torres señoriales levantadas en el campo, y que hasta hace poco eran consideradas como obras características de los siglos XIV y XV, tuvieron uno de sus periodos generatrices en la decimotercera centuria (García Álvarez-Busto y Muñiz López, 2010: 236). Además, a partir de la información textual conservada parece inferirse que algunos de estos caballeros, los más adinerados, mantenían una doble residencia que les permitía disfrutar de vivienda tanto en los núcleos urbanos como en sus casas solariegas en el campo (casas fuertes y torres) ${ }^{22}$. Por otro lado, la arqueología también nos informa de ciertas transformaciones que tuvieron lugar en la mesa y en la dieta de los señores a lo largo del siglo XIII ${ }^{23}$.

Poco sabemos por el contrario sobre el armamento o las armaduras que podían costearse estos caballeros ${ }^{24}$. De hecho desconocemos en qué taller de qué centro urbano se elaboraron

dición más modesta, como Alfonso García de la Pobla de Lena, "cavallero" que en 1281 arrendaba del monasterio de San Vicente el cellero de San Feliz. Años después, en 1301, su hijo Diego Alfonso, también caballero, renovaba el contrato con el monasterio (Ruiz de la Peña, 1977: 207).

20 En este sentido ya en 1248 Fernando III se dirigía a los "caballeros de la tierra" para que detuviesen su hostigamiento a los vecinos de Oviedo (Ruiz de la Peña, 1977: 201). A principios del siglo XIII destaca la figura de Gonzalo Peláez de Coalla, vasallo del obispo ovetense y -desde el cercano castillo de Tudela- gran hostigador de los intereses del concejo de Oviedo, el cual encomendará su defensa al caballero Suero del Dado y a otros miembros de los linajes de los Valdés y de los Bandujo (González Calle, 2011: 129-130).

21 Como ocurre en el castillo de Gauzón (Castrillón), desde 1222 en manos de encomenderos de la Orden de Santiago, entre los que destaca la figura de García González de Candamo, miembro de la nobleza regional y que disfrutaría como delegado regio de la tenencia del castillo en los primeros años del siglo XIII, y de su encomienda a partir de 1222 como Maestre de la Orden de Santiago (González Calle, 2003). En Gauzón el registro arqueológico ofrece un conjunto de armamentos y objetos de adorno y representación social propios de este estamento señorial (Muñiz López y García Álvarez-Busto, 2010: 192). O en el castillo de Curiel (Gijón), en cuya fase 3 -siglos XII-XIII- se documentó un variado repertorio material compuesto por broches, pinzas, alfileres, armamento, herraduras, bridas y una llave, asociado a la presencia de un delegado regio que disfrutaba de la tenencia de la fortificación (Gutiérrez González, 2003: 111).

22 Es el caso del caballero Ordoño Alvarez, quien en 1229 poseía una casa-palacio en Oviedo (Sanz Fuentes y Ruiz de la Peña, 1991: 189; Fernández Suárez, 1996: 251), citada en 1250 como "palacio de fillos de don Ordonno Aluariz" (Uría Ríu, 1967: 21; Fernández Conde et alii, 1978: 177-179; Álvarez Fernández, 2009: 249). Aunque los pocos ejemplos arquitectónicos conservados en las ciudades parecen estar más relacionados con el patrocinio del patriciado urbano enriquecido por el comercio. Es el caso de la casa-torre de la familia de Las Alas, una vivienda señorial dotada de bodega que se construye en el siglo XIV a partir de un torreón anterior (Requejo, Pérez y Calleja, 2007: 43), y del palacio de Valdecarzana, también en Avilés. Tradicionalmente la cronología de este edificio se enmarcaba en el siglo XIV, aunque recientemente su fábrica se ha "envejecido" con sólidos argumentos que lo llevan al siglo XIII (Alonso Álvarez, 1999) e incluso al XII (Argüello, 2009). En Oviedo está el caso de la casa señorial descrita en un documento de 1417 -que podría tratarse de la Casa de la Rúa-, y que contaba con torre, palacio, patio interior con galería, bodega, cámaras privadas, cuadra, hórreos y pozo (Uría Ríu, 1967: 25-26).

23 Nos estamos refiriendo más concretamente a la introducción de copas y vajillas de cerámica vidriada importada, procedentes principalmente de Francia, y vinculadas a la generalización del consumo de vino en la mesa de la nobleza, que aparecen documentadas en castillos, núcleos urbanos o monasterios (Fernández Calderón, Muñiz y García, 2014).

24 La escasa información que manejamos en Asturias para esta centuria proviene de los testamentos, como sucede con el de Pedro Díaz de Nava, fechado en 1289, y en el que se menciona: "Et deuo a Matías Ordónnez una loriga de cauallero que me enprestó que tien mio hermano Ruy Díaz de mí en garda, e una loriga e unas brefoneras e un escudo e una capellina e una gorguera que me enprestó, que mando que lo dían quanto el dixier en Dios e en sua alma que ualían. E la loriga de cauallero que le la día mio hermano. Et la loriga e las brefoneras que foe de Matías Ordónnez, e un lorigón mio, e un almofre apostizio, e un propunto mio, que me costó quaraenta maravedís en Seuilla"; o el de Arias Díaz, hijo de Don Arias Díaz de Noreña, en cuyo testamento de 1324 disponía: "Mando a Iohán Arias mio hermano las mias armas, 
las espuelas doradas que calzaba el caballero de Corias. En este sentido la arqueología tiene todavía un largo camino por recorrer en nuestra región, y la documentación escrita apenas nos aporta unas sucintas referencias acerca de la existencia de casqueros y freneros en el Oviedo del siglo XIII, encargados de elaborar yelmos y atalajes para los caballos; teniendo que esperar al siglo XV para constatar la consolidación de este gremio artesanal con la presencia en la capital del Principado de tres maestros armeros y dos açicaladores, encargándose estos últimos de reparar y abrillantar las armaduras (Argüello, 2008: 149 y 297).

Frente a este desconocimiento que la investigación arqueológica tiene de las cuestiones relacionadas con el día a día de estos caballeros a lo largo de su vida, disfrutamos de más información a la hora de analizar sus comportamientos funerarios. En este sentido la arqueología de la muerte empieza a identificar unos usos particulares mediante los cuales se advierte cómo los caballeros se diferencian claramente de los estamentos inferiores en el momento de escoger sus lugares de enterramiento. Los emplazamientos elegidos serán los espacios catedralicios urbanos o los monasterios rurales, tratando de evitar, siempre que fuera posible, los cementerios parroquiales comunes. El estudio de los diplomas y de la epigrafía aporta las mismas conclusiones al respecto ${ }^{25}$.

Así, sabemos que el caballero Gonzalo Fuertes de Cangas y su mujer Inés González, "moradores enna pobla de Cangas", fueron enterrados en la capilla de Santa María, la primitiva iglesia fundacional del monasterio de Corias, a cambio de una copiosa donación que habían realizado unos años antes, en 1364, y que incluía viñas, casas, bodegas, molinos y yuguerías entre otras heredades (García Leal, 1998: 119). Otro caballero, Alvar González de Allande, también había sido enterrado en este monasterio, en este caso en la sala capitular, tras haber realizado la pertinente donación pro anima ( $I b: 124)$.

El caballero enterrado con sus espuelas doradas en Corias ocupaba un lugar preferente de inhumación en el interior de la capilla, ubicándose en el transepto sur frente al altar dedicado a San Martín. Se trata de la única inhumación en fosa documentada en este espacio, en el cual se localizaba - sobre el pavimento - el cenotafio del rey Bermudo y su esposa. Su estatus le permitía acceder a uno de los espacios funerarios más reservados, diferenciándose del resto de miembros de la nobleza comarcal, inhumados preferentemente en el crucero y, sobre todo, en la nave del templo.

Por otro lado, y pese al carácter privilegiado del enterramiento, hay que resaltar que nos encontramos ante una sencilla inhumación en fosa, sin indicios que permitan deducir la existencia de un ataúd de madera o una tumba de fábrica ${ }^{26}$, por lo que probablemente el caballero se encontraba únicamente envuelto por un sudario de lino $^{27}$.

escudos, e balestas e llorigas" (Torrente Fernández, 1982: 219 y 241).

25 Es el caso por ejemplo de Pedro Díaz de Nava, quien en 1289 disponía en su testamento: "Mando mio corpo a sepoltura en San Veçente de Ouiedo"; o de Arias Díaz, quien en sus mandas testamentarias de 1324 establecía: "Mando mio cuerpo a sepultura en el monesterio de San Françisco de Oviedo, antel altar mayor, o en otro logar pertenesçiente commo convién a omme commo yo (...) Et se me y non quisieren enterrar assí commo yo o don Rodrigo Aluariz touier por bien, que me entierren en San Bartolomé de Naua, hu iaz don Ordonno, mio auuelo" (Torrente Fernández, 1982: 217 y 241). También en el siglo XIV, en 1348 concretamente, el caballero Suero Alfonso de Areces disponía en su testamento: "Mando mío cuerpo a sepultura en el monesterio de San Viçente de la çiddat de Oviedo, desde la puerta de la calostra endelantre, en bon logar e onrrado, pertenesçiente para mi" (González Calle, 2002: 281).

26 El empleo de ataúdes de madera en las sepulturas de estos caballeros asturianos está constatado en la documentación escrita de la época, como ejemplifica el enterramiento de Don Alfonso González de Maliayo, padre del caballero Suer Alfonso Beltrán, al entregar este último unos heredamientos a la abadía de San Salvador de Celorio "con condizión de enterrar en caxa honradamente los huesos de don Alfonso González de Maliayo y hazer un aniversario" (Fernández Martín, 1973: doc. 230; González Calle, 2011: 127).

$27 \mathrm{Al}$ respecto, en la iglesia francesa de Saint Pierre d'Engollon las excavaciones arqueológicas documentaron en el coro la sepultura de un caballero enterrado hacia 1339 con espuelas de estrella. El esqueleto también se encontraba inhumado en una simple fosa excavada en la tierra (Baud, 2010: 316). 
Ante la sencillez del enterramiento existían otros elementos que seguían diferenciando al caballero tras su fallecimiento: su ubicación preferente en el interior del templo ${ }^{28}$, y el ajuar funerario que le acompañaba (espadas, puñales, espuelas), conformando un repertorio de objetos con una inequívoca función de representación y diferenciación social ${ }^{29}$. La documentación escrita resulta también explícita al respecto, siendo especialmente revelador el testamento de Don Pedro de Castro, fechado en 1337, y en el que disponía ser enterrado con su espada y sus espuelas, en señal de haber sido caballero (Sánchez Ameijeiras, 1989: 433).

En teoría los escuderos no gozaban de estos elementos distintivos, aunque en la vida diaria esta barrera era habitualmente traspasada, tal y como refleja la propia legislación de la época. Así lo vemos en las Cortes de Valladolid de 1258, cuando se prohíbe el uso de espuelas doradas a los escuderos (García Cuadrado, 1993: 337); o en el decimosegundo artículo de las Cortes de Sevilla de 1261, bajo reinado de Alfonso X, en el que se especificaba que "ningún escudero non traya penna blanca nin calças, nin vista escarlata nin verde nin otro panno tinto, nin traya siella de barda nin argentada nin freno dorado nin espuelas doradas nin çapatos dorados nin sonbrero con orpel nin con argentpel nin con seda, nin coma con cavallero" (González Jiménez, 1998: 298).

La distancia real y social entre estos caballeros y escuderos era más frágil de lo que un principio podría parecer, aunque en los diplomas aparezcan diferenciados ${ }^{30}$. De hecho algunos autores han puesto de relieve las dificultades que existen para diferenciar entre sí a los caballeros y escuderos asturianos en el siglo XIII desde un punto de vista jurídico o fiscal (González Calle, 2002: 152), y más teniendo en cuenta que el dinero y la posibilidad de adquirir el equipo militar eran un mecanismo de ascenso social ${ }^{31}$. En este sentido llama poderosamente la atención la descripción que el cronista Ayala hace en 1353 del escudero Álvaro de Carreño, perteneciente a la hueste de Enrique de Trastámara: "e era asturiano e venía en un caballo castaño e un lorigón vestigo e sus quexotes e canilleras, e otros dos escuderos con él" (Ruiz de la Peña, 1977: 201), siendo un fiel reflejo de la imagen contenida en los poemas épicos del siglo XIII, en los que por caballero se entendía aquel guerrero que poseía un caballo y un armamento para el combate montado (Moreta Velayos, 1983: 9).

Nada más sabemos del anónimo personaje enterrado en la iglesia de Corias con sus acicates dorados, ni tan siquiera si habría seguido el cursus honorum propio del orden de caballería ${ }^{32}$. Así y todo el Libro Registro de Corias contiene una sugerente mención sobre un personaje, Pedro Artes, que es nombrado caballero por Bermudo Cabeza - quien a su vez estaba enfrentado con el conde Pedro-, recibiendo en el acto entre otros objetos unas espuelas doradas, unas

28 Hay que tener en cuenta además que será en estos siglos XIII y XIV cuando se desarrolle la creación de panteones familiares en los templos, dotados de monumentos funerarios, heráldica y epitafios laudatorios con la función de perpetuar la memoria de los linajes nobiliarios.

29 Son numerosos los ejemplos al respecto, como es el caso de la capilla de San Antonio del convento de San Francisco de Valladolid, donde se encontró en un nicho en la pared un enterramiento fechado en 1414 de un caballero de la Orden de la Banda que portaba espadas y espuelas doradas (Martínez Aguado, 1999: 337). Además desde el siglo XIV, pero con gran éxito en el XV, el simbolismo de la armadura del caballero, glosado en la época por el propio Ramón Llull, conquistaría las esculturas de las tapas de los sarcófagos como medio de representación del estatus social (Sánchez Ameijeiras, 1989: 428).

30 "Petro Gonsalviz, cavallero ... Petro Sannufo, suo escudero" (Sanz Fuentes y Ruiz de la Peña, 1991: 86)

31 Como refleja el testamento de Don Diego Iohannes, arcediano de Ribadeo, quien en su testamento de 1274 establecería que su sobrino Alfonso recibiría 100 maravedíes y un lecho de ropa "si for clerigo", o que le diesen "los C mrs. de que lly conprent armas" en el caso de que no se hiciese religioso (Ruiz de la Peña, 1977: 202).

32 Por el que habría alcanzado el grado de escudero a los 14 años, momento en el que se le entregaban una espada y unas espuelas de plata; y si realmente habría llegado a ser armado caballero al cumplir los 20 años, recibiendo entonces la espada envainada, el yelmo, el escudo y las espuelas doradas (López Sebastián, 2008: 34). 
calzas de escarlata, armas nuevas y un caballo ${ }^{33}$. Aunque no tenemos más datos que avalen una posible identificación entre el tal Pedro Artes y el personaje enterrado en Corias el texto sí permite verificar la existencia en aquel territorio y por aquellos tiempos - durante los siglos XII y XIII - de unos nobles que en vida mantenían unas relaciones militares en un contexto de conflictos señoriales que favorecía la creación de clientelas de carácter vasallático ${ }^{34}$, mientras que al enfrentarse a la muerte trataban de emular comportamientos de reyes y ricoshombres, implantando sus sepulturas en los lugares más destacados de los templos y haciéndose enterrar con honores, calzados con sus espuelas doradas.

\section{BIBLIOGRAFÍA}

Alonso Álvarez, R. (1999): "La clientela artística en el Avilés bajomedieval (ss. XII-XIV). Obras para la vida. Obras para la muerte", La nobleza peninsular en la Edad Media. León, 491-508.

Álvarez Fernández, M. (2009): Oviedo a fines de la Edad Media. Morfología urbana y política concejil. Oviedo: Ediciones KRK..

Álvarez Martínez, M. a S. (1999): El Románico en Asturias. Gijón: Trea.

Argüello Menéndez, J. J. (2008): La industria de la ciudad de Uviéu en la época medieval. Palma de Mallorca: Editorial Vessants.

Argüello Menéndez, J. J. (2009): Abilles. Palma de Mallorca: Editorial Vessants.

AA.VV. (2006): Tudela, el legado de una Catedral. Fundación para la Conservación del Patrimonio Histórico de Navarra.

Baud, A. (dir.) (2010): "Espaces ecclésial et liturgie au moyen age", n. ${ }^{\circ}$ 53, Travaux de la maison d l'Orient et de la Mediterranee. Lyon.

Blair, C. (1959): "Medieval swords and spurs in Toledo Cathedral", Journal of the Arms and Armour Society, III, 2, 41-51.

Beceiro Pita, I. y Córdoba de la Llave, R. (1990): Parentesco, poder y mentalidad. La nobleza castellana, siglos XII-XV. Madrid.

Calleja Puerta, M. (2001): El conde Suero Vermúdez, su parentela y su entorno social. La aristocracia asturleonesa en los siglos XI y XII. Oviedo: Ediciones KRK.

Camino Mayor, J.; Viniegra Pacheco, Y. y Estrada García. R. (2013): "Excavaciones arqueológicas en la fortificación altomedieval de El Muro (Cordal de La Mesa)", Excavaciones arqueológicas en Asturias 2007-2012, 7. Oviedo, 283-296.

Ceballos-Escalera Gila, A. de (2010): "Breves notas sobre los orígenes y la evolución de la heráldica hispana", El Escudo de Gipuzkoa. Una aproximación a la Heráldica Institucional de los territorios de lengua vasca, San Sebastián, 85-122.

Domínguez Bolaños, A. (2010): "Intervención arqueológica en la Colegiata de San Martín de Elines", Actuaciones arqueológicas en Cantabria. Arqueología de Gestión 2000-2003. Cantabria, 73-76.

Elorza Guinea, J. C. (2007): El Cid. Del hombre a la leyenda. Junta de Castilla y León y Sociedad Estatal de Conmemoraciones Culturales.

Erasun Cortés, R. y Monteiro Fause, F. L. (2008-2009): "Um conjunto de esporas medievais provenientes do Convento de S. Salvador de Vilar de Frades (Barcelos)", Portugalia, vol. XXIX-XXX, 179-192.

Fernández Calderón, N.; Muñiz López, I. y García Álvarez-Busto, A. (2014): “El castillo de Gauzón y el mar. Cerámica de importación y comercio atlántico en la Edad Media", I Symposium Internacional Gentes del mar. Historia y arqueología en el litoral del arco atlántico. Luanco, en prensa.

\footnotetext{
33 "Item ibi est alia hereditas que fuit de Petro Artes, et fecit eum militem Uermutus Cabeza cum manto de tirazes daranges e pelle de ipso panno e calzas descarlata e sporas deauratas e cauallo de CCC solidos de mergulieses e armas nouas de precio, e cum toto isto adubio habuit ad comitem Petrum, qui habebat guerram cum Uermuto Cabeza, e dissidauit ipse Uermutus Cabeza ad Petrum Artes, et ipse Petrus Ars pectauit eidem Uermuto totam suam partem de illa uilla de illa Mata" (Floriano, 1950, 109; García Leal, 2000: 133).

34 Para M. Calleja Puerta (2001: 387) el documento es un buen ejemplo de las relaciones vasalláticas y la actividad militar protagonizada por la nobleza local del occidente asturiano.
} 
Fernández Conde, F. J.;Torrente Fernández, I. y Noval Menéndez, G. de la (1978): El monasterio de San Pelayo. Historia y fuentes, vol. 1. Oviedo.

Fernández Martín, L. (1973): "Registro de escrituras del monasterio de San Salvador de Celorio", Boletín del Instituto de Estudios Asturianos, 78, 33-139.

Fernández Suárez, A. (1995): "Señorío y encomiendas en las tierras episcopales del valle del Trubia", Asturiensia Medievalia, 7, 147-164.

Fernández Suárez, A. (1996): "Orígenes y ascensión de un linaje nobiliario asturiano: los Álvarez de Noreña", Asturiensia Medievalia, 8, 239-261.

Floriano, A. C. (1950): El Libro Registro de Corias, 2 vols., Oviedo.

Friera Suárez, F. y Álvarez Rodríguez, M. ${ }^{\text {a }}$ L. (1984): "Once manifestaciones deportivas en el arte asturiano medieval", Aula Abierta, 41-42, 217-235.

García Álvarez-Busto, A. y Muñiz López, I. (2005): El territorio de Castrillón en la Edad Media. Piedras Blancas: Patronato Municipal de Cultura.

García Álvarez-Busto, A. y Muñiz López, I. (2010): Arqueología Medieval en Asturias. Gijón: Ediciones Trea.

García Álvarez-Busto, A. (2012a): "La iglesia fundacional del monasterio de Corias (Asturias) y los orígenes de la arquitectura monástica benedictina en el noroeste de la península ibérica", Pyrenae, $43,1,135-158$.

García Álvarez-Busto, A. (2012b): "La topografía funeraria del monasterio de Corias en la época medieval a partir de la arqueología y las fuentes escritas", Territorio, Sociedad y Poder, 7, Universidad de Oviedo: 129-177.

García Cuadrado, A. (1993): Las Cantigas. El Códice de Florencia. Murcia: Universidad de Murcia.

García Leal, A. (1998): Colección diplomática del monasterio de San Juan Bautista de Corias. Oviedo: Universidad de Oviedo.

García Leal, A. (2000): El Registro de Corias. Oviedo.

González Calle, J. A. (2001): La nobleza en Asturias durante la Baja Edad Media: génesis y evolución de linajes representativos.Oviedo: Universidad de Oviedo, tesis doctoral inédita.

González Calle, J. A. (2002): Los Escamprero y los Areces, escuderos de Las Regueras. La pequeña nobleza rural asturiana en la Baja Edad Media. Oviedo.

González Calle, J. A. (2003): "Don García González de Candamo: la transición entre aristocracia y nobleza en Asturias a comienzos del siglo XIII". Actas de Lorca 2002. Simposio de jóvenes medievalistas. Murcia, 111-128.

González Calle, J. A. (2011): "Mujeres en la nobleza bajomedieval asturiana: algunas biografías relevantes", Territorio, Sociedad y Poder, 6. Oviedo: Universidad de Oviedo: 121-152.

González Calle, J. A. (2012): "El linaje de los Valdés en Llanera durante la Edad Media (I): siglos XIIXIV", Perxuraos, Revista cultural de Llanera, 1, 27-49.

González Jiménez, M. (1998): “Cortes de Sevilla de 1261”, Historia, instituciones, documentos, 25, 295-312.

Gutiérrez González, J. A. (ed.) (2003): Peñaferruz (Gijón). El castillo de Curiel y su territorio. Gijón, Ayuntamiento de Gijón-VTP editorial.

Jular Pérez-Alfaro, C. (1990): Los adelantados y merinos mayores de León (siglos XIII-XV). León: Universidad de León.

López Sebastián, P. (2008): "Espuelas doradas de Armentia", Akobe: restauración y conservación de bienes culturales, $9,34-38$.

Manso Porto, C. (1989): "El convento de Santo Domingo de Ortigueira", Anuario brigantino, n. ${ }^{\circ} 12$, 209-220.

Martínez Aguado, I. (1999): "Un retablo para el convento de San Francisco de Valladolid del pintor Manuel Mateo", Boletín del Seminario de Estudios de Arte y Arqueología, 65, 335-341.

Martínez Sopena, P. (2008): "La aristocracia hispánica. Castilla y León (siglos X-XIII)", Bulletin du centre d'études médiévales d'Auxerre, Hors-série n. ${ }^{\circ} 2$, http://cem.revues.org.

Marreno Cabrera, J. A. (1998): "Una perspectiva desde el siglo XI: A la luz del Poema del Cid", Militaría. Revista de cultura militar, 11, 155-170. Madrid: Servicio de Publicaciones de la UCM.

Menéndez Pidal, G. (1986): La España del siglo XIII leída en imágenes. Madrid: Real Academia de la Historia. 
Moreta Velayos, S. (1983): "El caballero en los poemas épicos castellanos del siglo XIII: Datos para un estudio del léxico y de la ideología de la clase feudal", Studia historica. Historia medieval, 1. Salamanca: Universidad de Salamanca, 5-28.

Muñiz López, I. (2008): "Vida y muerte de Menendo Enalso, un caballero asturiano del siglo XII y su familia", Territorio, Sociedad y Poder, 3. Oviedo: Universidad de Oviedo, 157-194.

Muñiz López, I. y García Álvarez-Busto, A. (2010): "El castillo de Gauzón (Castrillón, Asturias). Campañas de 2007-2009. El proceso de feudalización entre la Antigüedad Tardía y la Edad Media a través de una fortaleza", Territorio, Sociedad y Poder, 5. Oviedo: Universidad de Oviedo, 81-121.

Requejo Pagés, O.; Pérez González, R. y Calleja Fernández, S. (2007): “Arqueología e Historia”, Palacio de Camposagrado de Avilés. Avilés, 18-92.

Ruiz de la Peña Solar, J. I. (1977): Historia de Asturias. Baja Edad Media. Salinas: Ed. Ayalga.

Sánchez Ameijeiras, M. ${ }^{a}$ R. (1989): "El arnés y el armamento del caballero medieval gallego (13501450)", Acta historica et archaeologica mediaevalia, 10, Universidad de Barcelona, 427-436.

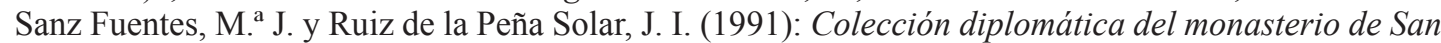
Vicente de Oviedo. Siglos XIII-XV. Oviedo.

Soler del Campo, A. (1987): "Estudio comparativo de un conjunto de espuelas bajomedievales", II Congreso de Arqueología Medieval. Madrid, 179-189.

Soler del Campo, A. (2007): “Acicate”. En J. C. Elorza Guinea (ed), El Cid. Del hombre a la leyenda. Burgos, 222.

Torrente Fernández, I. (1982): El dominio del monasterio de San Bartolomé de Nava (Siglos XIII-XVI). Oviedo.

Uría Ríu, J. (1967): "Contribución a la historia de la arquitectura regional, las casas de Oviedo en la diplomática de los siglos XIII al XVI", Boletín del Instituto de Estudios Asturianos, LX, Oviedo, 3-30.

Yzquierdo Perrín, R. (2012): "La miniatura en Galicia en la Baja Edad Media", M. a del C. Lacarra Ducay, (coord.), La miniatura y el grabado de la Baja Edad Media en los archivos españoles, Zaragoza,103-156.

Recibido: 01/08/2013

Aceptado:12/06/2014 